\title{
Developing Human Capital in Africa: Carving a Role for Human Resource Professionals and Practitioners
}

\author{
Dr Aminu Mamman \\ University of Manchester \\ Global Development Institute \\ Manchester, UK \\ aminu.mamman@manchester.ac.uk \\ Professor Ken Kamoche \\ University of Nottingham \\ Nottingham University Business School \\ Nottingham, U.K \\ Ken.kamoche@nottingham.ac.uk
}

Dr. Hamza B. Zakaria

Ghana Institute of Management and Public Administration

School of Public Service and Governance

P. O. Box AH50, Achimota

Accra

Ghana

hzakaria@gimpa.edu.gh

Motolani Agbebi

$\mathrm{PhD}$ Candidate

University of Tampere

School of Management

Tampere, Finland

Motolani.agbebi@uta.fi 


\title{
Developing Human Capital in Africa: Carving a Role for Human Resource Professionals and Practitioners
}

\begin{abstract}
Africa is a continent with remarkable economic potential yet the least developed largely due to its inadequate human capital to transform this potential into social and economic development. The focus on provision of classroom education as the cornerstone of human capital development in Africa has not produced the desirable outcomes expected. We see an important role in this process within the workplace, and thus argue that the role of Human Resource (HR) professionals in Human Capital development in Africa deserves serious attention. The paper outlines why and how HR professionals can contribute to the development of Africa's human capital. It also highlights the challenges HR professionals will face and the competencies they will need to address the challenges. The paper concludes with suggestions for further research.
\end{abstract}

Keywords: Human Capital Development; Human Resource professionals; HR roles; African Development

\section{Introduction}

The demand for Africa's natural resources, the opportunities for investment, and Africa's burgeoning consumer market have ushered in substantial foreign investments from around the world, and increasingly from Asia (eg Kamoche and Siebers, 2015). For example, foreign direct investment (FDI) into Africa grew from US\$18 billion in 2005 to US\$66.5 billion in 2015 (Africa Investment Report 2016). However, observers view the low level of Africa's human capital (Asiedu, 2004; Lumbila, 2005), its institutional weaknesses, and its ineffective organizations (Pedersen \& McCormick, 1999; Renard, 2011; Schiere, 2011) as inhibiting the continent from realising its potential, yet, Africa's potential is now widely acknowledged (for example Kamoche, Siebers, Mamman \& Newenham-Kahindi, 2015). Therefore, research on the causes of Africa's failure to capitalize on the opportunities globalization has offered has grown enormously. From within this literature, we should take particular note of research and theory on human capital and its relationship with development and productivity by human resource management and development experts (Collins \& Smith 2006; Collins \& Clark, 2003; Garavan, 2007; Nishii, Lepak, \& Schneider, 2008; McGuire, 2014; Polyhart, Weekley, \& Baughman, 2006; Polyhart \& Moliterno, 2011), as well as human capital theorists (Becker \& Woessmann, 2009; Hanushek \& Woessmann 2009; Lynham \& Cunningham, 2006; McLean, 2006; Sohn, 2010; Wang, \& Swanson, 2008; Zula \& Chermack, 2007). This work suggests that nations wishing to take full advantage of globalization will do well if they focus on developing their human and organizational 
capacity, so as to convert their opportunities into concrete economic and social development. For example, central to the research and debate on Africa's development is the argument that effective development of human capital is the key to realising Africa's enormous economic potential - which would be the proper foundation for the eradication of poverty and for meeting other social challenges (AfDB, 2011; 2014; Hall \& Jones, 1999; Lynham \& Cunningham, 2006).

In spite of the strong argument for the potential contribution of human capital to Africa's development, there are limitations and challenges in the literature that prevent the effective adoption of human capital agenda especially in Sub-Saharan Africa (SSA). Specifically, the current literature often provides broad arguments in support of the significance of human capital development without delineating how and who should play the role of translating the human capital agenda into practice at the organizational level where social and economic value is created. The absence of adequate clarity regarding who is best placed to provide intellectual and practical guidance in the implementation of human capital development agenda stifles theoretical and practical utility of the argument that Africa's development can be enhanced by developing its human capital.

Aim: The primary aim of this paper is to contribute to the advancement of Human Capital Development (HCD) framework in Africa. The Economic Commission for Africa (ECA, 2017) report has considered the improvement of the productive capacities of the African labour force as critical for achieving sustainable development goals (SDGs). The report argues that, to achieve this, there is a need for investment in skills and health of all segments of the population. It can be argued that central to the limitation of the current debate on the role of human capital in Africa's development lies in the neglect of the role of organizations and their HRD professionals in contributing to the development of Africa's human capital. The current approach appears to assume that mass production of education with limited focus on its utilization will lead to human capital development. However, Economic Commission for Africa and UN Women reports have argued for a needs-based approach to human capital development in Africa (ECA, 2017; UN Women, 2017). Secondly, the emphasis on knowledge, skills and ability as the main constituents of human capital is another limitation in the current debate. In fact, in line with the widely reported conceptualization of human capital (Becker, 1964), SDGs have incorporated a wider 
dimension of HCD (ECA, 2017). Similarly, some researchers have drawn human resource development implications of SDGs (Zarestky \& Collins, 2017). Therefore, as contribution the paper demonstrates how HR professionals can pay important role to Africa's SDGs through HCD. First, the paper underscores the relevance of HCD to the implementation of Africa's SDGs and Agenda 2063 by echoing the argument that human agency is the foundation on which social and economic development is built. Second, the paper discusses and demonstrates why and how HCD can only be completed at the point of production of goods and services, not in the classroom. Third, the paper provides convincing argument and sheds light on why HCD is too important to be left in the hands of those who have limited intellectual and professional experience in human capital creation. For example, the paper demonstrates how HR practitioners have a key role to play in the implementation of Africa's development agenda especially in relation to SDGs' focus on quality education, eradication of poverty and inequality, and innovation and industrialization. Fourth, this paper advances taxonomies of HR practitioners' roles, challenges and competencies based on a generic and unique African context. Finally, this paper contributes important directions for future research. It is worth pointing out that the paper focuses more on SSA rather than the whole continent given that development challenges on the continent are more acute in the SSA. However, much of what is presented in this paper is relevant to HCD in developing countries.

\section{Methodology}

We have reviewed relevant studies, monographs, papers and reports focusing on human capital development with emphasis on international development and developing countries in particular. We have referred to reputable journals in the area of HRD, HRM, Management, Economics, Public Policy and Administration, including Humans Resources Development International, International Journal of Human Resource Management; Human Resource Development Quarterly, Human Resources Development Review, Academy of Management Journal, Journal of Monetary Economics, Policy Studies, Quarterly Journal of Economics, World Development, and Africa Journal of Management. Similarly, we have referred to relevant development reports such as World Development reports, UNDP reports, UN reports, Africa Commission and World Bank reports. The review of the papers, reports and monographs was deliberately intended to gain broader understanding and shed light on the complexity and multi-disciplinarity of the topic of human capital development especially 
in the African context. This methodology enabled us to address the main aim and objectives of the paper.

\section{Integrating Macro and Micro perspectives on Human Capital Development}

It is widely believed that HCD through quantitative expansion of educational opportunities is the key to economic growth, with its concomitant reduction of inequality, eradication of poverty, and boost to employment (McLean, 2006; Todaro, 1997). However, much of the approach to human capital development focuses largely on the provision of education, with inadequate focus on other elements of human capital, namely skills, ability and other work-related qualities (AfDB, 2011). Although most research has linked educational attainment with national productivity, employability, and earnings (Psacharopoulos \& Patrinos 2004; Trostel, Walker, \& Woolley 2002), there are some views, with associated research evidence, that caution against making this simplistic assumption (Pritchett 1996; Son, 2010). In fact, the World Development Report (2018: 2) argues that schooling is not the same as learning. Thus, measuring the number of years in school is not always a predictor of labour productivity or personal income. We add to this caution by arguing that unless the measure of educational attainment includes all the elements that constitute human capital and the organizational contexts within which people are employed, Africa's focus on the provision of education as the cornerstone of its human capital development agenda of 2063 (ECA, 2017) might not achieve the desirable outcomes. Hence, given that the quality of education in Africa has deteriorated over the years (AfDB, 2014; World Bank, 2007), it is imperative to factor in the organizational contexts where the products of the educational system will ultimately end up. This is because when an educational system is not up to scratch, the input necessary for the provision of skills and abilities as key components of human capital resources will be compromised (AfDB, 2011). In fact African Development Bank’s Human Capital Development strategy highlighted that "There is a large disconnect between graduate skills learned in education institutions and the needs of the labour market” (AfDB, 2014:6).

The debate on human capital imperative for Africa's development has failed to achieve an adequate integration of macro issues (i.e. outputs of educational systems) and micro issues (i.e. further development and utilisation of the outputs). There needs to be an adequate articulation of what human capital is, how the vision of human capital development (albeit narrowly focused on education) can be implemented, and who are the right people to 
provide the intellectual and practical lead in the implementation at micro (organizational and enterprise) levels. In this regard, within African institutions and organizations, we argue that the people with the potential capacity to make a significant contribution in providing the intellectual and practical guidance for the development of Africa's human capital are the human resource development (HRD) professionals and practitioners. For example, in policy terms, Zarestky \& Collins (2017) have suggested how HRD as a discipline can contribute to the formulation of national policies on talent and organizational development that will lead to the achievement of SDGs goals of economic growth and employment.

Observers have rightly continued to espouse the virtues and relevance of human capital in Africa's quest for development. However, inadequate attention has been paid to how this vision of developing Africa's human capital can be translated in practical terms into effective institutions, organizations, and enterprises where economic activities take place. Most significantly, there is inadequate recognition of the need to determine, at the organizational and enterprise levels, as to who should play the key role of translating the African vision of human capital development into practice. Although experts view human capital as the possession of knowledge, skills, and "other” human qualities (Schmidt \& Hunter, 1998), state interventions in human capital (Baro \& Lee, 1994) and experts on Africa's human capital appear to concentrate on the provision of education and health (Behrman \& Wolfe 1983; 1993; Bennell, 1996; Glewwe \& Jacoby, 1995; Nsouli, 2000; Sahn, 1992) rather than all the elements that together constitute human capital. As a consequence, organizations and business enterprises in Africa are left shouldering the responsibility of completing the task of developing Africa's human capital through the provision of skills, abilities, and "other" work-related human qualities. The United Nations Development Programme (UNDP) and the Millennium Development Goals (MGD) have advocated the need for Africa and developing countries to focus on the provision of education as a means of eradicating poverty. However, SDG and the recent development report 2018 have rightly emphasized quality education as key to the achievement of sustainable development. Similarly, the African Development Bank has recently focused on human capital development as one of the cornerstones of its strategy for economic and social development on the continent (AfDB 2014). We argue that, within an African context at least, although education provides the foundation for human capital, without skills, ability and work-related values, there needs to be a more nuanced approach to creating human capital. We acknowledge that the issue of the inadequacy of the product of educational system is not 
confined to Africa and the developing countries. For example, a survey by the UK's Forum for Private Business (2008) reported that the majority of the respondents believe the graduates of secondary and tertiary educational system do not have adequate skills required by the labour market. Our point of departure in this debate is that, while employers in developed countries have better capacity to fill the skills gap left by the educational system especially through state support and tax incentives, private employers in Africa do not have such capacity.

As pointed out by researchers and experts, employment or self-employment is where HCD is finally completed not in the classroom (Bhorat \& Lundall, 2004). In fact, empirical evidence suggests that African labour productivity is amongst the lowest in the world (Appleton \& Balihuta, 1996; Bigsten et al. 2000; Söderbom \& Teal, 2004; UNISA, 2014). Yet there is inadequate articulation of the role of African employers, and most significantly relevant African professionals, in the development and utilisation of Africa's human capital. Although African governments have embarked on public sector transformation with human capital development as part of its aims (Karyeija, 2012; Wohlgemuth et al. 1998), a legitimate question can be asked about the human resource capacity of the institutions and organizations dedicated to implementing the reforms. As a continent that is reported to have many ineffective organizations and institutions (Easterly \& Levine, 1997; Nsouli, 2000; Wohlgemuth et al. 1998), SSA needs the support of relevant professionals with the knowledge, skills and ability to develop and utilise the potential of its people in a systematic and professional way to ensure the achievement of SDG-related HCD goals. Their role should be to advise, guide and implement human capital development at institutional and organizational levels (Nsouli, 2000; Rodrik, 1997).

\section{Institutional and Organizational Capacities for Africa's Development}

Africa has an essential need for extra capacity at institutional and organizational levels to convert the potential advantages of its global economic and political integration into economic and social development (Karyeija, 2012; North, 1990). The two critical capacities for social and economic development are human capacity and organizational capacity (Wohlgemuth et al. 1998). The latter is dependent on the former. Several writers have proposed models of organizational and individual capacity building in Africa and beyond (Austin, et al. 2009; 2011; Bellman, 1993; Berg, 1993; Blumenthal, 2003; Cosner, 2009; Hilderbrand, et.al. 1997; Hope, 2011; Jones, 2001; Modisane, 2018; Swanson, 1995). At the 
organizational level, several elements of capacity have been identified. These include appropriate organizational systems and structure that allows its members to operate efficiently and effectively (Preston, 2005). According to Glisson (1981), the capacity of an organization to achieve its goals will depend on the efficiency and effectiveness of its subsystems. This include the formal structure, psychological subsystem, the technological subsystem, and goals and values of the organization Glisson (1981: 261). Similarly, Blumenthal (2007) offered a model of organizational capacity building which focuses on explicit goals of organizational capacity building, supportive environment for training, multiple training approaches that are theoretical and experiential, and the use of multiple training tools.

At the individual level, capacity relates to knowledge, skills, ability and job-related attitudes to carry tasks and roles to achieve organizational objectives (Austin et, al. 2011; Choi, \& Ruona, 2011). For example Blumenthal (2003) proposed that organizations should have managers that have capacity to generate financial/human/informational resources, capacity to manage/change organizational culture, capacity to identify/support/demonstrate leadership, and capacity to create/support attitudes towards change. Similarly, other researchers have identified additional dimensions of skills and intelligence required to perform organizational roles and tasks (Gill, 2003). The first dimension is the intellectual/cognitive dimension. It relates to the ability to comprehend what is required to be done and the ability to do it. This is "the electoral or cognitive ability to perceive and understand information, reason with it, imagine possibilities, use intuition, make judgements, solve problems and make decisions” (Gill, 2003). The second dimension of skills and competencies is the ability to derive meanings that are shared with others in the organization. The final dimension of skills and competencies required is emotional intelligence skills. These skills and competencies are not salient features of African educational curriculum. Developing these skills and competencies is within the purview of HRD practitioners.

Irrespective of the sector (public or private) or size of the organization (micro, small, medium, large) there is a need for managerial as well as "technical/professional" capacity for sustainable success (DeGhetto, Gray; \& Kiggundu, 2016). Developing these capacities of developmental institutions and organizations is critical to the implementation of SDGs (Hope, 2011). As Hope (2011:60) pointed out “Capacity development is therefore not a stand-alone training intervention but rather a strategically coordinated set of activities aimed at individuals, institutions and sectors”. Hope (2011) further argued that capacity development 
is also about "strengthening the performance capabilities of individuals, organisations and societies". We believe that HRD practitioners have a crucial role to play in building these capacities.

Without the two capacities in key institutions (public sector) and organizations (including private enterprises), the achievement of many of the aspects of SDGs and Africa's Agenda 2063 will not be realised. For example, without human capacity at various levels of systems and structures of development, it is hard to see how the SDG and Agenda 2063 goals of eradicating poverty, quality education and innovation and industrialization can be achieved. In a nutshell, human capacity is the foundation for institutional and organizational capacity. In fact, some development economists have argued that human development is the foundation on which social, economic and political development is built (Burkey, 1993). From the Africa's Agenda 2063 aspirations, human capital should provide the wherewithal for people at various levels of the value chain to make informed and right decisions and act accordingly for the benefits of the entity they serve, be it in the private or public sector. This should result in "a prosperous Africa based on inclusive growth and sustainable development” (DeGhetto; et. al. 2016: 95). Organizational capacity is the architecture and infrastructure which enables good decisions to be taken, effective actions to be carried out, and value to be created by social and economic actors and entities (Daft \& Weik, 1984; Mintzberg, 1983). Organizational capacity provides the moral and economic justification for members to be sufficiently motivated to make the right decision and act accordingly. Hence, organizational capacity elicits appropriate behaviours which lead to productivity. These capacities are not sold in a bottle, neither can they be acquired by African organizations and business enterprises overnight, given that most African countries cannot afford to acquire foreign human capital. While the State can provide the foundation for human capital development through provision of education, the human capital Africa needs will have to be developed by government agencies, non-governmental organizations and business enterprises. Therefore, there is a need for a systematic and strategic approach to the issue of translating Africa's SDGs and human capital vision into practical reality at several levels not just educational institutions. This is where HRD expertise on talent and organizational development comes to the fore (Zarestky \& Collins, 2017). 


\section{Intellectual and Practical roles of African HRD professionals}

This paper argues that the HR profession is well equipped to make a significant contribution in developing the human and organizational capacities that can lead to the realisation of Africa's potential within the context of SDGs and Agenda 2063. To appreciate the potential role of the HR profession, it is worth noting that the profession has grown in leaps and bounds, extending beyond a purely administrative role into the realm of national human resource development (Byrd, 2017; Cho \& McLean, 2004; Lynham \& Cunningham, 2006; McLean, 2006; Modisane, 2017; Zarestky \& Collins, 2017), strategy formulation (Beer 1997; Boxall \& Purcell, 2011; Caldwell, 2008), and developing knowledge and talent at the organizational and national levels (Cohen, 1991; Cohen \& Levinthal, 1990; Collins \& Smith, 2006; Gibb \& Zhang, 2016). HR as a body of practitioners is now able to satisfy all the criteria of a profession in its own right, which includes: a body of knowledge; a code of ethics and discipline; certification, education and training; a governing body; legal status; research; contribution to society; independence; and recognition (Ulrich; Younger; Brockbank; Ulrich, 2013). Regarding its relevance to contributing to Africa's institutional, organizational and business enterprise challenges, the profession has also acquired the relevant expertise in organizational change and development, including public service reform, application of ICT to provide solutions to people management issues, the development of leadership and managerial competencies, and development of structure and systems for the implementation of good governance systems and socially responsible enterprises. It is worth pointing out also that HR professionals are well versed in knowledge of how adults learn and acquire skills in and outside the workplace, which is vital for implementing the SDG-related HCD goals. They are also adept in diagnosing the skills and learning characteristics of adults in and outside the workplace. Given that work attitudes and values are considered as part of human capital, HR professionals' knowledge of the causes of human behaviour in the work setting will enable them help develop the systems and structures that will elicit appropriate workplace behaviour.

This neglect of the practical dimension of HCD seems to imply that the implementation of Africa's SDGs and human capital vision can be undertaken without a HRD professional foundation. We argue that the adoption of a liberal market approach to human capital development, where the emphasis is on populating the African labour market with theory-driven job-seekers devoid of other key components of human capital (i.e. skills, ability and values), and waiting for market forces to do their trick, will not lead to the 
realisation of Africa's agenda 2063 and SDGs-related goals. Therefore, there is an urgent need to co-opt HR professionals as key partners in the implementation of human capital development in Africa.

Another reason why HR professionals are equipped to make a significant contribution to the realization of Africa's SDGs and the needed human capital to realise them, is because Africa's business environment - which is characterised by an "institutional void" at its core requires certain professions to extend their roles outside the traditional organizational boundaries to fill the gaping hole left by institutions and state agencies (Bakuwa \& Mamman, 2012; Mamman et al. 2012; Mamman \& Bakuwa 2012). In fact, during the colonial era and the immediate aftermath, certain key professionals such as teachers and medical practitioners complemented and sometimes filled the "void" created by institutional inadequacies or absences - in the areas of social services and governance, for example.

Africa is at a stage where the role of key professions needs to be redefined within the context of the "institutional void" and the associated social and economic challenges (Easterly and Levine, 1997; Nsouli, 2000; Wohlgemuth et al., 1998). The HR profession has the essential theoretical and practical foundation to understand the human dimensions of the economic and social challenges facing Africa, and how individuals and organizations can be supported to address them. Take the case of HIV/AIDS as an example: HR practitioners, with their background in health and safety, can and do play key roles in helping the implementation of international and national policy on the disease, even at the societal level (Bakuwa \& Mamman, 2012; Mamman, Kamoche, \& Bakuwa, 2012; Mamman \& Bakuwa, 2012). HR professionals can also act as a conduit through which international and national social interventions can be implemented at the community level. Such interventions might include health and safety (Kangethe, 2005), environmental protection through its "green HRM” programmes (Berrone \& Gomez-Mejia, 2009; Brio, Fernandez, \& Junquera, 2007; Madsen \& Ulhoi 2001; Maignan, Ferrell, \& Hult 1999; Muster \& Schrader, 2011), and social integration and inter-ethnic harmony through its diversity programmes (Chatman \& O’Reilly, 2004; Chattopadhyay, 1999; 2003; Jackson \& Joshi, 2004; Jackson, Joshi, \& Erhardt, 2003). With a strong background in the knowledge and skills related to pedagogy, curriculum development and training, HR professionals can make a significant impact on any aspects of a human capital development initiative within and outside the entity which they serve. 


\section{Challenges to HR professionals in Africa}

Although the HR profession can and sometimes does play some of the roles identified above, it is not widely reported upon nor formally recognised, nor is it actively pursued in terms of the roles and activities that can contribute to Africa's organizational and institutional effectiveness, thus leading to socio-economic development in the long run. It must be noted, however, that for the HR function and HR professionals to take on the mammoth tasks identified above, they need to upgrade their competencies to enable them to cope with the specific challenges which are characteristic of developing countries, especially in Africa. African organizations and institutions face many challenges that impact on their productivity and ability to achieve their mission. Most of the challenges have direct implications for the competencies of HR professionals. In the following table (Table 1) we summarise and discuss the key challenges that call for the development of specific competencies to enable HR professionals to contribute to human capital development in Africa.

Table 1. Challenges to HR professionals in Africa

\begin{tabular}{|c|c|}
\hline Challenges & Implications \\
\hline $\begin{array}{l}\text { 1. Lack of understanding and appreciation of } \\
\text { the potential role of the HR function in Africa }\end{array}$ & $\begin{array}{l}\text { When a profession is not well regarded by potential } \\
\text { stakeholders, its advice is less likely to be heeded }\end{array}$ \\
\hline $\begin{array}{l}\text { 2. Lack of institutionalisation of } \mathrm{HR} \text { as a } \\
\text { profession on the continent }\end{array}$ & $\begin{array}{l}\text { Absence of formal structure and systems to regulate } \\
\text { and guide the profession will limit its impact on HCD } \\
\text { in Africa }\end{array}$ \\
\hline $\begin{array}{l}\text { 3. Many of the HR practitioners do not have a } \\
\text { professional or academic background in the } \\
\text { field of HR }\end{array}$ & $\begin{array}{l}\text { Academic and professional qualifications will enhance } \\
\text { the credibility of the profession and its impact on HCD } \\
\text { in Africa }\end{array}$ \\
\hline $\begin{array}{l}\text { 4. Lack of strong institutional frameworks and } \\
\text { regulation to guide employment relations }\end{array}$ & $\begin{array}{l}\text { Strong institutional frameworks and enforcement of } \\
\text { regulation on employment matters will provide the } \\
\text { professionals with the opportunity to demonstrate their } \\
\text { professionalism and make impact on HCD }\end{array}$ \\
\hline $\begin{array}{l}\text { 5. Lack of a critical mass of HR professionals to } \\
\text { champion the development of the profession }\end{array}$ & $\begin{array}{l}\text { For the profession to flourish and make impact, there } \\
\text { need to a critical mass of experts that will demonstrate } \\
\text { the utility of the profession to stakeholders }\end{array}$ \\
\hline $\begin{array}{l}\text { 6. African professional environment is generally } \\
\text { characterised by a porous boundary }\end{array}$ & $\begin{array}{l}\text { Porous boundary of any profession does not ensure the } \\
\text { credibility of such a profession }\end{array}$ \\
\hline $\begin{array}{l}\text { 7. Wider challenges pertaining to Africa's } \\
\text { organizational and business environment }\end{array}$ & $\begin{array}{l}\text { The organizational and business environment can } \\
\text { enable or constrain the impact of a profession such as } \\
\text { HRD profession }\end{array}$ \\
\hline
\end{tabular}


The first challenge is the lack of understanding and appreciation of the potential role of the HR function in Africa, particularly in African organizations. Although HR practitioners in other parts of the world face similar challenges (Kochan, 1997; Legge, 2005; Ulrich, 1997; 1998), this is related to the fact that, in developed countries, administrators with little or no background in HR are able to carry out some of the administrative HR functions. Also, organizations in developed countries have effective institutions and face a less daunting business environment, and this also could arguably justify the lack of recognition of a unique HR function. In Africa, however, the level of management and administrative competency is often low, justifying the need for HR professionals to be regarded as amongst the categories of professionals that can make a significant impact on organizational operation and strategy through their contribution to the implementation of the human capital development. The second related challenge is the lack of institutionalisation of HR as a profession on the continent. This challenge has to be tackled by the HR practitioners themselves. Although there are HR professional bodies in some countries, their profile is relatively low compared to their counterparts in other professions such as Law, Accountancy, Architecture, and Engineering. In order for the HR function to achieve its potential in African organizations and beyond, therefore, it has to enhance its professional profile.

The third challenge is that many of the HR practitioners do not have a professional or academic background in the field of HR. On a continent where paper qualifications count for a lot, HR practitioners will not be taken seriously by line managers and colleagues who practice their trade unless they are backed up by a relevant professional or academic qualification. The fourth challenge faced by HR practitioners is the lack of strong institutional frameworks and regulation to guide employment relations (Karyeija, 2012; Wohlgemuth et al. 1998). No profession can practice and thrive in its trade without strong institutions to regulate the activities which the profession caters for. Paradoxically, the weakness of the institutional frameworks for regulating employment in Africa provides HR professionals with the opportunity to make a difference by helping to provide the knowledge and skills for building institutions and sustaining them.

The fifth challenge is the lack of a critical mass of HR professionals to champion the development of the profession. Although a number of overseas-educated HR professionals have gone back to Africa, many remain unemployed or underemployed, or employed in jobs unrelated to HR, due to the economic situation in many countries. Many organizations that employ HR graduates do not recognize the potential of the HR profession. Closely related to 
the issue of a critical mass of HR professionals is inadequate training and the dearth of educational institutions to develop the skills and knowledge of current and future HR professionals at a level and standard required for the implementation of the African human capital development agenda.

The sixth challenge is that the African professional environment is generally characterised by a porous boundary. This has allowed many people to practice the HR trade as consultants, even though they lack adequate knowledge, skills and experience to do this properly. Under these circumstances, where there is no clear boundary to ensure the protection of the credibility of genuine HR professionals, it is very difficult to develop and professionalise HR practice.

Finally, apart from the challenges which directly affect HR professionals, there are also wider challenges pertaining to Africa's organizational and business environment that can impact on the practice of the HR profession. The role of any professional is to provide solution to a problem. Hence, the image of any profession is largely dependent on the real and perceived capacity of the profession to solve problems. So, what are the typical problems in African organizations and institutions that can impact on the HR function and HR professionals? Although the institutional and organizational environment in SSA varies from one country to the other, several writers have documented the challenges of the African organizational environment especially in SSA. Amongst these are: corruption, inter-ethnic rivalry in the workplace and the labour market, politicisation of the public sector and fledgling institutions, lack of technical and managerial competencies, leadership deficiencies, inadequate physical and financial resources, poor work ethic, colonial legacy, culture and tradition, and ineffective management of tribal and religious diversity at the workplace level (Brunetti, et al. 1998; Budhwar \& Debrah 2004; Kamoche et al. 2004; Karyeija, 2012; Okpara \& Wynn 2008; Pedersen \& McCormick, 1999; van Donge; Henley \& Lewis, 2013). These challenges form a cocktail of problems that not only constrain organizational effectiveness but also impact on HR practitioners' ability to apply the knowledge and skills required to make their organizations and enterprises effective.

\section{Required Competencies for HR professionals in Africa}

The challenges identified regarding Africa's organizational environment provide HR professionals with an opportunity to help develop the relevant human and organizational 
capacities to mitigate their impact. To address them, HR professionals need micro and macro approaches. The former deal with the profession itself, while the latter deal with the environment of the profession. Hence, the micro approach is about building the relevant competencies for HR practitioners. This would enable them to influence debate and practice in organizations and the wider business and institutional environments. The achievement of these objectives should be a catalyst for taking on the wider macro issues where the longterm strategy should be focused on how to improve organizational effectiveness within the context of the wider socio-economic environment. Therefore, making a significant and noticeable contribution will require the acquisition of generic skills and competencies (i.e. professional competencies) as well as idiosyncratic competencies that will help find relevant solutions to the challenges facing organizations in the African organizational environment. In addition to these competencies, HR professionals, like any other professional, would need the competencies required to deal with their own career and personal development (Mcdonald \& Hite, 2005). Table 2 summarises these competencies. 
Table 2. Suggestive Competencies for HR professionals in Africa

\begin{tabular}{|c|c|}
\hline Organizational activities & Generic Competency \\
\hline Strategic dimension & $\begin{array}{l}\text { Managerial competencies: competency to help senior managers to } \\
\text { articulate vision, enact environment, and realise the vision. }\end{array}$ \\
\hline Resource acquisition & $\begin{array}{l}\text { Input-based competencies: competency to help the organization to } \\
\text { identify the needed organizational resources, particularly human } \\
\text { resources, that enable the transformation processes to create social and } \\
\text { economic value. }\end{array}$ \\
\hline Resource deployment and conversion & $\begin{array}{l}\text { Output-based competencies: competency to help the organization to } \\
\text { develop knowledge-based invisible assets such as image, reputation in } \\
\text { quality, and stakeholders' support. }\end{array}$ \\
\hline Transformation & $\begin{array}{l}\text { Transformational competencies: competency to help the organization } \\
\text { develop systems and processes to transform inputs into outputs } \\
\text { especially through organizational learning and organizational culture }\end{array}$ \\
\hline $\begin{array}{c}\text { Features of African Organizational } \\
\text { Environment }\end{array}$ & Idiosyncratic Competency \\
\hline Weak institutions & $\begin{array}{l}\text { Competency to help senior managers diagnose and understand the } \\
\text { institutional environment, develop tools for the development of } \\
\text { appropriate rules and regulations that should guide government } \\
\text { agencies and the private sector. Competency to develop database of } \\
\text { knowledge and skills providers required for institution-building }\end{array}$ \\
\hline $\begin{array}{l}\text { Inadequate managerial and technical } \\
\text { skills }\end{array}$ & $\begin{array}{l}\text { Competency to establish and run effective human resource department } \\
\text { and programmes to enable the development of the needed human } \\
\text { capital that fits the internal and external environment }\end{array}$ \\
\hline Inadequate financial resources & $\begin{array}{l}\text { Competency to help the organization to develop systems and } \\
\text { processes for effective use of resources }\end{array}$ \\
\hline $\begin{array}{l}\text { Blurring boundary } \begin{array}{r}\text { between } \\
\text { organization and the external }\end{array} \\
\text { environment (e.g. wider community } \\
\text { and the society) }\end{array}$ & $\begin{array}{l}\text { Competency in interacting with external stakeholders; Competency in } \\
\text { developing organizational culture with social responsibility outlook; } \\
\text { Competency in analysing and determining the overlap between } \\
\text { organizational environment and the wider society and the implications } \\
\text { for human capital development; Competency in stakeholder analyses. }\end{array}$ \\
\hline Culture and Tradition & $\begin{array}{l}\text { Competency in helping organization to diagnose and understand the } \\
\text { impact of culture and tradition on the organizational systems, } \\
\text { processes and employee behaviours; Competency in developing } \\
\text { systems, processes and organizational culture that mitigate the } \\
\text { negative impact of culture and tradition. }\end{array}$ \\
\hline Ethnic diversity & $\begin{array}{l}\text { Competency in managing diversity such as developing diversity } \\
\text { strategy, policy, programme and, systems for the implementation of } \\
\text { the policy and programme }\end{array}$ \\
\hline $\begin{array}{l}\text { Corruption and Politicization of the } \\
\text { public sector }\end{array}$ & $\begin{array}{l}\text { Competency in developing HRM systems and programmes to develop } \\
\text { the culture of professionalism and integrity; Competency in } \\
\text { organizational change and development; Competency in personal } \\
\text { development }\end{array}$ \\
\hline $\begin{array}{l}\text { Poverty (income, health and } \\
\text { education) }\end{array}$ & $\begin{array}{l}\text { Competency in helping organization to diagnose and understand the } \\
\text { impact of societal poverty on employees' behaviour as well as on the } \\
\text { organizational systems and processes. }\end{array}$ \\
\hline
\end{tabular}


Generic Competencies: This paper began by highlighting the potential role of HR professionals in the realisation of Africa's vision for human capital development as outlined in SDGs and Africa Agenda 2063. To play such roles, HR professionals need to help develop human and organizational capacities for the organizations in which they reside, ie, they need to help organizations develop their own competencies. What competencies do organizations need? We adopt Lado and Wilson's (1994) categorisation of organizational competencies to illustrate where HR professionals in Africa can make significant impacts on human and organizational capacities (see Table 1). Lado and Wilson (1994) identified the following competencies that are required to deliver success in any organization: Managerial competencies (unique capabilities of leaders to articulate vision, enact environment, and realise the vision); Input-based competencies (organizational resources, particularly human resources, that enable the transformation processes to create social and economic value); Output-based competencies (knowledge-based invisible assets such as image, reputation in quality, and customer loyalty, all of which are made possible by the decisions and actions of organizational members); and Transformational competencies (related to the capacity to transform inputs into outputs with the help of innovation, entrepreneurship, organizational learning and organizational culture). African HR professionals can help deliver these competencies by developing HR systems that enable the acquisition and utilisation of the organizational competencies. For example, they can develop an HR system that enables the acquisition of managerial competencies, and which in turn enables senior managers to create a vision for their organizations and help realise that vision (Lado \& Wilson, 1994). Secondly, African HR professionals need to help remove and replace competence-destroying HR and organizational systems which inhibit the acquisition and utilisation of organizational competencies. In a nutshell, it is almost impossible to develop the human capital needed by the African economy without developing the HR and organizational systems that enable the acquisition and utilisation of organizational competencies identified above.

Other generic competencies relate to personal professional competencies. These are essential because HR professionals cannot contribute to the organization which they serve if they are unable to demonstrate competence in providing solutions. HR professionals should be amongst the professionals that demonstrate knowledge, skills, and abilities pertaining to people management and organizational effectiveness. They should also be role models for work-related human values through demonstration of professionalism, adherence to policy, and above all self-control and discipline at work. Therefore, the generic competencies that 
will demonstrate professionalism amongst colleagues and line managers relate to (a) business awareness, (b) strategic capability, (c) organizational effectiveness, (d) internal consultancy, (e) service delivery, and (f) professional development (Brockbank et al. 1999). These generic competencies, if possessed, will allow the HR practitioner to make the initial contribution and develop the image of professionalism.

Idiosyncratic Competencies: HR professionals need broader competencies that relate to the unique socio-economic environment of Africa. We argued that HR professionals would need to play wider roles beyond the organizations that employ them. They will be playing such roles because of the increasing blurring of the boundaries between organizations and the wider societies (Mamman; Bakuwa \& Kamoche, 2012). Health epidemics, insecurity and inter-ethnic conflict are some of the features of the African environment that can impact on organizational effectiveness due to their impact on employees. Therefore, HR professionals need to carve out a role and the required competencies that will mitigate the impact of such key features of the African business environment (see Table 2 above). In addition to wider African business environment, there is need for industry-specific competencies to enable the organization to achieve its objectives. Hence, there are key questions HR professionals need to ask and seek answers for, such as within Africa's organizational environment, how can HR professionals identify competencies needed in the hospitality and transportation industries? What tools and techniques would be needed to perform this role effectively within a given industry? Even within the same industry, configurational rather than contingency perspectives might prevail (Arthur, 1992; 1994; Delery \& Doty, 1996). Furthermore, resource-based theorists and human capital theorists argue that each business should have firm-specific competencies in order to maintain its competitive advantage (Barney, 1991; Becker, 1964; Flamholtz \& Lacey, 1981).

In a nutshell, HR professionals need to be aware of the key success factors of their industry. This will enable them to offer advice on the appropriate people to recruit into the industry and the type of competencies the employees need in order to operate effectively. Within the context of the discourse on human capital vision, the identification and development of industry-specific knowledge, skills and ability through the contribution of the HR professionals should lead to the development of Africa's stock of human capital. This is because a nation's human capital is the summation of human capital developed through 
education as well as through employment. Indeed the development of the competencies will enable the HR professionals to make a significant contribution to the organization and beyond. This can then set the foundation for acquiring better status to function as credible professionals (Legge, 2005; Storey, 1995; Ulrich \& Broadbank, 2005).

\section{Conclusion and Directions for Research}

Conclusion: Africa is one of the few areas with substantial untapped potential in the world and yet the least developed largely due to its limited human capital to turn its potential into social and economic development. The paper argues that the role of human resource (HR) professionals in HCD of Africa has not received the recognition it deserves. Therefore, the paper outlines why and how HR professionals can contribute to the development of Africa's human capital. It also highlights the challenges HR professionals will face and the suggestive competencies they will need to address the challenges. The following section outlines some areas for further investigation that can shed light on the role HR professionals can play in developing Africa’s human capital.

Direction for Research: There is potentially a major research agenda for those interested in human capital development in Africa in general, and those interested in matters concerning HR professionals in particular. The issue of competencies needed by HR professionals to tackle the challenges of Africa's institutional and organizational environment has undoubtedly opened up avenues for research that can lead to the development of Africaspecific competency model that can complement the generic competency model to enable human capital development on the continent. Research questions might include: How does Africa's unique institutional and organizational environment impact on the HR role and HR functions? What aspects of personal development programmes and initiatives would HR professionals need? Where can they access such programmes? Organization-specific and industry-specific competencies have major implications for research. For example, these competencies would entail the identification of organization and sector-specific competencies within the African context. Does this therefore mean that HR professionals would need to develop specific competencies for their organization? To play new and effective roles within a context of blurring boundaries will require new competencies. What should the competencies be? How can they be developed? Who can provide them? These are some of 
the questions that we expect will spur further debate in this important field. Finally, given the unique circumstances of the African business environment, there is a need for research on the organizational and HR systems that will deliver needed HR professionals' competencies. Given the diversity of the African socio-economic environment, research will also be needed to determine the degree to which the needed organizational competencies may vary and the reason for the variance. Correspondingly, research will be needed to establish the appropriate variation of organizational and HR systems across Africa.

\section{References}

AfDB (2011). AfDB’s Human Capital Development Strategy (2012-2016). http://www.afdb.org/fileadmin/uploads/afdb/Documents/PolicyDocuments/FINAL\%20human\%20capital\%20development\%20strategy\%20\%2820122016\%29.pdf

AfDB (2014). The Bank’s Human Capital Strategy for Africa. OSHD Department. http://www.afdb.org/fileadmin/uploads/afdb/Documents/PolicyDocuments/AfDB_Human_Capital_Strategy_for_Africa_2014-2018.pdf

Africa Investment Report 2016 (2017).

https://www.camara.es/sites/default/files/publicaciones/the-africa-investment-report-2016.pdf Accessed 13/08/2017

Appleton, S., \& Balihuta, A. (1996). Education and agricultural productivity: evidence from Uganda. Journal of International Development, 8(3), 415-444.

Arthur, J. B. (1992). The link between business strategy and industrial relations systems in American steel mini-mills. Industrial and Labor Relations Review, 45: 488-506.

Arthur, J. B. (1994). Effects of human resource systems on manufacturing performance and turnover. Academy of Management Journal, 37: 670-687.

Austin, M. J., Regan, K., and Samples, M. (2009). ). Building managerial and organizational capacity in nonprofit human service organizations through a leadership development program. Berkeley. CA: University of California

Austin, M. J., Regan, K., Samples, M. W., Schwartz, S. L., \& Carnochan, S. (2011). Building managerial and organizational capacity in nonprofit human service organizations through a leadership development program. Administration in Social Work, 35(3), 258-281.

Bakuwa, R \& Mamman, A. (2012). Factors hindering the adoption of HIV/AIDS Workplace policies: Evidence from private sector companies in Malawi. International Journal of Human Resource Management. 23(14), 2917-2937(21) 
Barney, J. (1991). Firm resources and sustained competitive advantage. Journal of Management, 17: 99-129.

Barro, Robert J. And Jong-Wha Lee (1994), “International comparisons of educational attainment “, Journal of Monetary Economics, 23(3)

Becker, G. S. (1964). Human capital. New York: Columbia Uni-versity Press.

Becker, S. O. \& Woessmann, L (2009). Was Weber Wrong? A Human Capital Theory of Protestant Economic History. The Quarterly Journal of Economics, 124 (2): 531-596

Beer, M. (1997). "The Transformation of the Human Resource Function: Resolving the Tension between a Traditional Administrative and a New Strategic Role”. Human Resource Management, 36 (1), 49-56.

Behrman, J. and B. Wolfe (1983) "The socio-economic impact of schooling in a developing country”, Review of Economics and Statistics, 66 (2), 296-303.

Behrman, Jere (1993) "The economic rationale for investing in nutrition in developing countries”, World Development, Vol.21, No.1 (1993), pp.1745-72

Bellman, B., Tindimubona, A., \& Arias Jr, A. (1993). Technology transfer in global networking: Capacity building in Africa and Latin America. Global networks: Computers and international communication, 237-254.

Bennell, Paul (1996) 'Rates of Return to Education: does the Conventional Pattern Prevail in sub-Saharan Africa?’World Development, 24, 183-200

Berg, E. J. (1993). Rethinking technical cooperation: reforms for capacity building in Africa. United Nations Development Programme.

Berrone, P., \& Gomez-Mejia, L. (2009). Environmental Performance and Executive Compensation: An Integrated Agency-institutional Perspective. Academy of Management Journal, 52(1), 103-126.

Bigsten, A., Isaksson, A., Soderbom, M., Collier, P., Zeufack, A., Dercon, S., . . Pattillo, C. (2000). Rates of Return on Physical and Human Capital in Africa's Manufacturing Sector. Economic Development and Cultural Change, 48(4), 801-827.

Boxall, P and Purcell, J (2011). Strategy and Human Resource Management. ${ }^{\text {rd }}$ Edition. Basingstoke: Palgrave Macmillan

Brio, J.A., Fernandez, E., \& Junquera, B. (2007). Management and Employee Involvement in Achieving an Environmental Action-based Competitive Advantage: An Empirical Study. The International Journal of HRM, 18(4), 491-522.

Bhorat, H., \& Lundall, P. (2004). Employment, wages and skills development: firm-specific effects - evidence from a firm survey in South Africa. The South African Journal of Economics, 72(5), 1023- 1056. 
Blumenthal, B. (2003). Investing in capacity building: A guide to high-impact approaches. Foundation Center.

Blumenthal, B. (2007). A framework to compare leadership development programs. New York, NY: Community Resource Exchange.

Brunetti, A., Kisunko, G. and Weder, B. (1998), Credibility of Rules and Economic Growth: Evidence from a Worldwide Survey of the Private Sector, World Bank Economic Review, 12 (3): 353-384

Budhwar, P.S., and Debrah, Y. (2004), Human Resource Management in Developing Countries, London: Routledge

Burkey, S (1993) People first, Zed Books, London

Byrd, M.Y. (2017) Does HRD have a moral duty to respond to matters of social injustice?, Human Resource Development International, 21:1, 311, DOI: $\underline{10.1080 / 13678868.2017 .1344419}$

Caldwell, R. (2008). ”HR business partner competency models: re-contextualising effectiveness”. Human Resource Management Journal. 18 (3): 275-294.

Chatman, J., \& O'Reilly, C. (2004). Asymmetric reactions to work group sex diversity among men and women. Academy of Management Journal, 47(2).

Chattopadhyay, P. (1999). Beyond direct and symmetrical effects: The influence of demographic dissimilarity on organizational citizenship behavior. Academy of Management Journal, 42(3), 273-287.

Chattopadhyay, P. (2003). Can dissimilarity lead to positive outcomes? The influence of open versus closed minds. Journal of Organizational Behavior, 24, 295-312.

Choi, M., \& Ruona, W. E. (2011). Individual readiness for organizational change and its implications for human resource and organization development. Human Resource Development Review, 10(1), 46-73.

Collins, C. J., \& Smith, K. G. 2006. Knowledge exchange and combination: The role of human resource practices in the performance of high-technology firms. Academy of Management Journal, 49: 544-560.

Collins, C., \& Clark, K. 2003. Strategic human resource practices, top management team social networks, and firm performance: the role of human resource practices in creating organizational competitive advantage. Academy of Management Journal, 46: 740-751.

Cohen, M. D. 1991. Individual learning and organizational routine: emerging connections. Organization Science, 2: 135-139.

Cohen, W., \& Levinthal, D. (1990). Absorptive Capacity: A new perspective on organizational learning and innovation. Administrative Science Quarterly, 35: 128-152. 
Cosner, S. (2009). Building organizational capacity through trust. Educational Administration Quarterly, 45(2), 248-291

Daft, R.L. and Weick, K.E. (1984) 'Toward a Model of Organizations as Interpretation Systems', Academy of Management Review 9: 284-95.

DeGhetto, K., Gray, J. R., \& Kiggundu, M. N. (2016). The African Union's Agenda 2063: Aspirations, Challenges, and Opportunities for Management Research. Africa Journal of Management, 2(1), 93-116.

Delery, J. E., \& Doty, D. H. (1996). Modes of theorizing in strategic human resource management: Tests of universalistic, contingency, and configurational performance predictions. Academy of Management Journal, 39: 802-835.

Easterly W and Levine, R (1997). "Africa's Growth Tragedy: Policies and Ethnic Divisions," Quarterly Journal of Economics, Vol. 112 (November), pp. 1203-50.

ECA (2017). Africa Sustainable Development Report: Tracking Progress on Agenda 2063 and the Sustainable Development Goals.

https://www.afdb.org/fileadmin/uploads/afdb/Documents/GenericDocuments/2017_Africa_Sustainable_Development_Report_Executive_summary_EN.pdf Accessed 15/02/2018

Fischer, S; Hernández-Catá, E and Khan, M.S (1998). "Africa: Is This the Turning Point?" IMF Paper on Policy Analysis and Assessment 98/6 (Washington: International Monetary Fund).

Flamholtz, E., \& Lacey, J. (1981). Personnel management: Hu-man capital theory and human resource accounting. Los Angeles: Institute of Industrial Relations, UCLA.

Garavan, T. N. (2007). A strategic perspective on human resource development. Advances in Developing Human Resources, 9(1), 11-30.

Gibb, S \& Zhang, S (2016). Guanxi influence and talent management in Chinese organisations; evidence from the real estate sector, Human Resource Development International, 20:1, 79-98,

Gill, R (2003). Change management - or change leadership? Journal of Change Management, 3(4), 307-318

Glewwe, Paul and Hanan Jacoby (1995) “An economic analysis of delayed primary school enrolment in a low income country: the role of early childhood nutrition”, Review of Economics and Statistics, 77, 156-169

Hall R.E and Jones, C.I (1999), "Why Do Some Countries Produce So Much More Output Per Worker Than Others?" Quarterly Journal of Economics, Vol. 114 (February), pp. 83-116.

Hanushek, E., and Kimko, D (2000). "Schooling, Labor Force Quality, and the Growth of Nations.” American Economic Review 90(5):1184-208. 
Hanushek, E., and Woessmann, L (2009). Do Better Schools Lead to More Growth? Cognitive Skills, Economic Outcomes, and Causation. NBER Working Paper No. 14633, National Bureau of Economic Research, Massachusetts.

Hilderbrand, M. E., Grindle, M. S., Trostle, J. A., Sommerfeld, J. U., Simon, J. L., Lippincott III, D. F., ... \& Contreras, M. E. (1997). Getting good government: capacity building in the public sectors of developing countries. Cambridge, MA: Harvard University Press.

Hope Sr, K. R. (2011). Investing in capacity development: towards an implementation framework. Policy Studies, 32(1), 59-72.

Jackson, S. E., \& Joshi, A. (2004). Diversity in social context: A multi-attribute, multi-level analysis of team diversity and sales performance. Journal of Organizational Behaviour, 25, 675-702.

Jackson, S. E., Joshi, A., \& Erhardt, N. L. (2003). Recent research on team and organizational diversity: SWOT analysis and implications. Journal of Management, 29(6), 801-830.

Jones, M. L. (2001). Sustainable organizational capacity building: is organizational learning a key? The International Journal of Human Resource Management, 12(1), 91-98.

Kamoche, K. \& L.Q. Siebers, (2015) 'Chinese investments in Africa: Toward a post-colonial perspective,' International Journal of Human Resource Management, 26(21), 2718-2743.

Kamoche, K., Siebers, L.Q., Mamman, A. \& Newenham-Kahindi, A. (2015), The dynamics of managing people in the diverse cultural and institutional context of Africa. Personnel Review, 44(3): 330-345.

Kamoche, K., Debra, Y., Horwitz, F., and Muuka, G. (eds.) (2004), 'Conclusion: Toward Research Agenda,' in Managing Human Resources in Africa, London: Routledge, pp. 183190.

Karyeija, G.K (2012). Public Sector Reforms in Africa: What Lessons have we Learnt. Forum for Development Studies; Vol. 39, No. 1, 105-124

Kochan, T.A. (1997). "Rebalancing the role of Human Resources”. In Ulrich, D., Losey, M.R. and Lake, G. (eds). Tomorrow's HR Management: 48 Thought Leaders Call for Change. New York: John Wiley, pp. 119-129.

Lado, A.A and Wilson, M.C (1994). Human Resource Systems and Sustained Competitive Advantage: A Competency-Based Perspective. The Academy of Management Review, Vol. 19 (4), 699-727

Legge, K. (2005). Human Resource Management: Rhetorics and Realities. London: Palgrave Macmillan.

Lepak D.P and Snell, S.A (1999). The Human Resource Architecture: Toward a Theory of Human Capital Allocation and Development. The Academy of Management Review, Vol. 24, No. 1, pp. 31-48 
Lynham, S. A., \& Cunningham, P. W. (2006), National human resource development in transitioning societies in the developing world: Concepts and challenges, Advances in Developing Human Resources, 8(1), 11-135

Madsen, H., \& Ulhoi, J. P. (2001). Greening of Human Resources: Environmental Awareness and Training Interests within the Workforce. Industrial Management \& Data Systems, 101(2), 57-63

Maignan, I., Ferrell, O. C., \& Hult, G. T. M. (1999). Corporate Citizenship: Cultural Antecedents and Business Benefits. Journal of the Academy of Marketing Science, 27(4), 455-469.

Mamman, A \& Bakuwa, R (2012). What factors influence the adoption of workplace policies in African organisations? An exploratory study of private sector companies' adoption of workplace policies in Malawi. Journal of General Management, Vol. 37 No. 3, pp. 39-60

Mamman, A; Kamoche, K \& Bakuwa, R (2012). The Role of Human Resource Practitioners within a Context: Should there be a unique role for African HR Practitioners? International Journal of Academy of Organizational Behaviour Management, Vol. 1 (1), 1-40

McDonald, K.S and Hite, L.M (2005). Reviving the Relevance of Career Development in Human Resource Development. Human Resource Development Review, vol. 4 (4), 418-439

McGuire, D. (2014). Human resource development. Sage.

Mintzberg, H. (1983). Structure in Fives. Prentice-Hall International

Modisane, K. T. (2018). Finding the niche to reposition leadership in Africa's developing economies for the global highway: review of literature on leadership development programmes-methods and techniques. Human Resource Development International, 21(1), $12-23$.

Muster, V and Schrader, U (2011).Green Work-Life Balance: A New Perspective for Green HRM. German Journal of Research in Human Resource Management, 25(2)

North, D (1990). Institutions, institutional Change and Economic Performance. Cambridge: Cambridge University Press.

Nsouli, S.M (2000). Capacity Building in Africa: The Role of International Financial Institutions. Finance and Development, 37(4), 1-4

Okpara, J.O and Wynn, P (2008). Human resource management practices in a transition economy: Challenges and prospects. Management Research News, Vol. 31 Iss: 1, pp.57 - 76

Pedersen, P.O and McCormick, D (1999). African business systems in globalizing World. The Journal of Modern African Studies. 37(1), 109-135

Ployhart, R.E and Moliterno, P.M (2011). Emergence of Human capital resource: A multilevel model. Academy of Management Review, 36(1), 127-150 
Ployhart, R.E, Weekley, J and Baughman, K (2006). The structure and function of human capital emergence: A multi-level examination of the attraction-selection-attraction model. Academy of Management Journal, 49(4), 661-677

Pritchett, L. 1996. Where Has All the Education Gone? World Bank Policy Research Working Paper 1581, Washington, DC.

Psacharopoulos, G., and H. Patrinos. 2004a. "Returns to Investment in Education: A Further Update.” Education Economics 12(2):111-34

Rodrik, D. (1997), "TFPG Controversies, Institutions, and Economic Performance in East Asia," NBER Working Paper No. 5914 (Cambridge, Massachusetts: National Bureau of Economic Research).

Sahn, David (1992), "Public expenditures in sub-Saharan Africa during a period of economic reforms”, World Development, Vol.20, No.5, p.673-693.

Söderbom, M. M., \& Teal, F. J. (2004). Size and efficiency in African manufacturing firms: evidence from firm-level panel data. Journal of Development Economics, 73(1), 369-394.

Sohn, H.H (2010). Human Capital Development, Asian Development Review, 27(2), 29-56

Storey, J. (1995). Human Resource Management: a critical text. London: Routledge.

Swanson, R. A. (1995). Human resource development: Performance is the key. Human Resource Development Quarterly, 6(2), 207-213.

Sweetland, S.R (1996). Human Capital Theory: Foundations of a Field of Inquiry. Review Of Educational Research, vol. 66 (3) 341-359

Todaro, M. P. (1997) Economic Development. Reading, Mass.: Addison-Wesley

Trostel, P., I. Walker, and P. Woolley. 2002. "Estimates of the Economic Return to Schooling for 28 Countries.” Labour Economics 9:1-16

Ulrich, D (1997). HR champions. Boston, MA: Harvard Business School Press.

Ulrich, D (1998). “A new mandate for HR”. Harvard Business Review, 76, Jan-Feb: 124-134

Ulrich, D. and Broadbank, W. (2005). “The HR Value Proposition”. Harvard Business School Press, Boston, Massachusetts.

UNIDO, (2009). Foreign Direct Investment in Sub-Saharan Africa: Determinants and Location Decisions. Geneva. Research and Statistics Branch Working Paper 08/2008

UNISA, (2014). SA labour productivity at its lowest in 46 years. http://www.unisa.ac.za/news/index.php/2014/01/sa-labour-productivity-at-its-lowest-in-46years/ 
UN Women (2017). The Sustainable Development Goals (Sdgs) And Africa's Agenda 2063. https://sustainabledevelopment.un.org/content/documents/2441UNWomenSDGReport.pdf. Accessed 15/02/2018

van Donge, J.K; Henley, D and Lewis, P (2012). Tracking Development in South-East Asia and Sub-Saharan Africa: The Primacy of Policy. Development Policy Review, 30 (s1): s5-24

Wang, G. G., \& Swanson, R. A. (2008). The idea of national HRD: An analysis based on economics and theory development methodology. Human Resource Development Review, 7(1), 79-106.

Wohlgemuth, L; Carlsson, J and Kifle, H (1998). Institution building and leadership in Africa. Stockholm: Nordiska Afrikainstitutet

World Bank (2007). Higher Education Quality Assurance in Sub-Saharan Africa: Status, Challenges, Opportunities, and Promising Practices. World Bank Working Papers 124: Africa Human Development Series. Washington D.C

World Development Report (2018). Learning to realise education's promise. International Bank for Reconstruction and Development / The World Bank 1818 H Street NW, Washington, DC 20433

Zarestky, J., \& Collins, J. C. (2017). Supporting the United Nations' 2030 sustainable development goals: a call for international HRD action. Human Resource Development International, 20(5), 371-381.

Zula, K.J and Chermack, T.J (2007). Integrative Literature Review: Human Capital Planning: A Review of Literature and Implications for Human Resource Development. Human Resource Development Review vol. 6 no. 3 245-26 